\title{
Water availability and land subsidence in the Central Valley, California, USA
}

\author{
Claudia C. Faunt ${ }^{1} \cdot$ Michelle Sneed $^{2} \cdot$ Jon Traum $^{2} \cdot$ Justin T. Brandt $^{2}$
}

Received: 14 July 2015 / Accepted: 1 November 2015 /Published online: 17 November 2015

(C) The Author(s) 2015. This article is published with open access at Springerlink.com

\begin{abstract}
The Central Valley in California (USA) covers about $52,000 \mathrm{~km}^{2}$ and is one of the most productive agricultural regions in the world. This agriculture relies heavily on surface-water diversions and groundwater pumpage to meet irrigation water demand. Because the valley is semi-arid and surface-water availability varies substantially, agriculture relies heavily on local groundwater. In the southern two thirds of the valley, the San Joaquin Valley, historic and recent groundwater pumpage has caused significant and extensive drawdowns, aquifer-system compaction and subsidence. During recent drought periods (2007-2009 and 2012-present), groundwater pumping has increased owing to a combination of decreased surface-water availability and land-use changes. Declining groundwater levels, approaching or surpassing historical low levels, have caused accelerated and renewed compaction and subsidence that likely is mostly permanent. The subsidence has caused operational, maintenance, and construction-design problems for water-delivery and floodcontrol canals in the San Joaquin Valley. Planning for the effects of continued subsidence in the area is important for water agencies. As land use, managed aquifer recharge, and surface-water availability continue to vary, long-term groundwater-level and subsidence monitoring and modelling are critical to understanding the dynamics of historical and continued
\end{abstract}

Published in the theme issue "Land Subsidence Processes"

Claudia C. Faunt

ccfaunt@usgs.gov

1 U.S. Geological Survey, California Water Science Center, San Diego Projects Office, 4165 Spruance Road, Suite 200, San Diego, CA 92024, USA

2 U.S. Geological Survey, California Water Science Center, $6000 \mathrm{~J}$ Street, Placer Hall, Sacramento, CA 95819, USA groundwater use resulting in additional water-level and groundwater storage declines, and associated subsidence. Modeling tools such as the Central Valley Hydrologic Model, can be used in the evaluation of management strategies to mitigate adverse impacts due to subsidence while also optimizing water availability. This knowledge will be critical for successful implementation of recent legislation aimed toward sustainable groundwater use.

Keywords Subsidence - Groundwater/surface-water relations $\cdot$ Compaction $\cdot$ USA $\cdot$ Geohazards

\section{Introduction and background}

California's Central Valley covers about $52,000 \mathrm{~km}^{2}$ and is one of the most productive agricultural regions in the world. More than 250 different crops are grown in the broad alluvial filled structural trough with an estimated value exceeding $\$ 20$ billion per year (Faunt 2009; Fig. 1). Central Valley agriculture depends on state and federal water systems that divert surface water, predominantly sourced from Sierra Nevada snowmelt, to agricultural fields. Because the valley is semiarid and the availability of surface water varies substantially from year to year, agriculture developed a reliance on groundwater. Long-term groundwater-level declines can result in a one-time release of "water of compaction" from compacting fine-grained deposits, which causes land subsidence (Galloway et al. 1999). More than half of the thickness of the aquifer system is composed of fine-grained sediments, including clays, silts, and sandy or silty clays (Williamson et al. 1989) that are susceptible to aquifer-system compaction if depressurized by groundwater pumping.

Prior to the early 1960 s, groundwater pumpage exceeded surface-water deliveries in the southern two thirds of the 


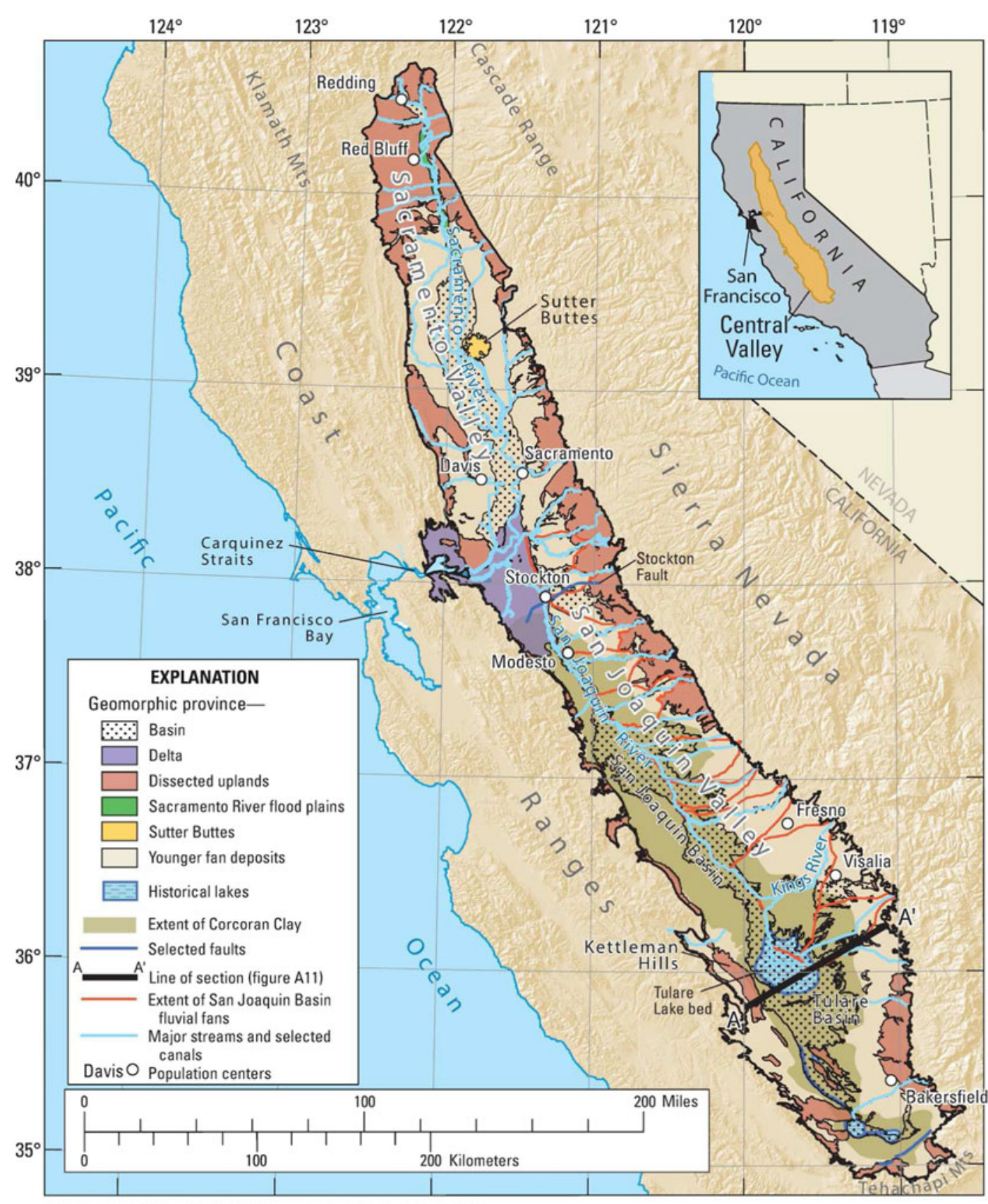

Shaded relief derived from U.S. Geological Survey National Elevation Dataset, 2006 Albers Equal Area Conic Projection

Fig. 1 Map showing major geomorphic provinces, fluvial fans of the San Joaquin Basin (Weissmann et al. 2005), and other selected geologic features in California's Central Valley (modified from Faunt 2009)

Central Valley, the San Joaquin Valley. The extensive withdrawal of groundwater led to historic low groundwater levels on the west side of the San Joaquin Valley, groundwater storage losses (Fig. 2) and widespread aquifer-system compaction and land subsidence. Land subsidence in the Central Valley from groundwater pumping began in the mid-1920s (Poland et al. 1975; Bertoldi et al. 1991; Galloway and Riley 1999), and by 1970, about half of the San Joaquin Valley, or about 13, $500 \mathrm{~km}^{2}$, had subsided more than $0.3 \mathrm{~m}$ (Poland et al. 1975).
Locally, $9 \mathrm{~m}$ of subsidence had occurred by the early $1980 \mathrm{~s}$ (Ireland 1986).

Partially in response to these water-level declines and associated aquifer-system compaction and land subsidence, an extensive surface-water delivery system was developed to redistribute some of the water from north to south and east to west. Surface-water imports from the Delta-Mendota Canal since the early 1950s and the California Aqueduct since the early 1970s resulted in decreased groundwater pumping in 
Fig. 2 Graph showing surface water deliveries and cumulative groundwater storage changes simulated by the Central Valley Hydrologic Model (CVHM).

Modified from Faunt (2009)

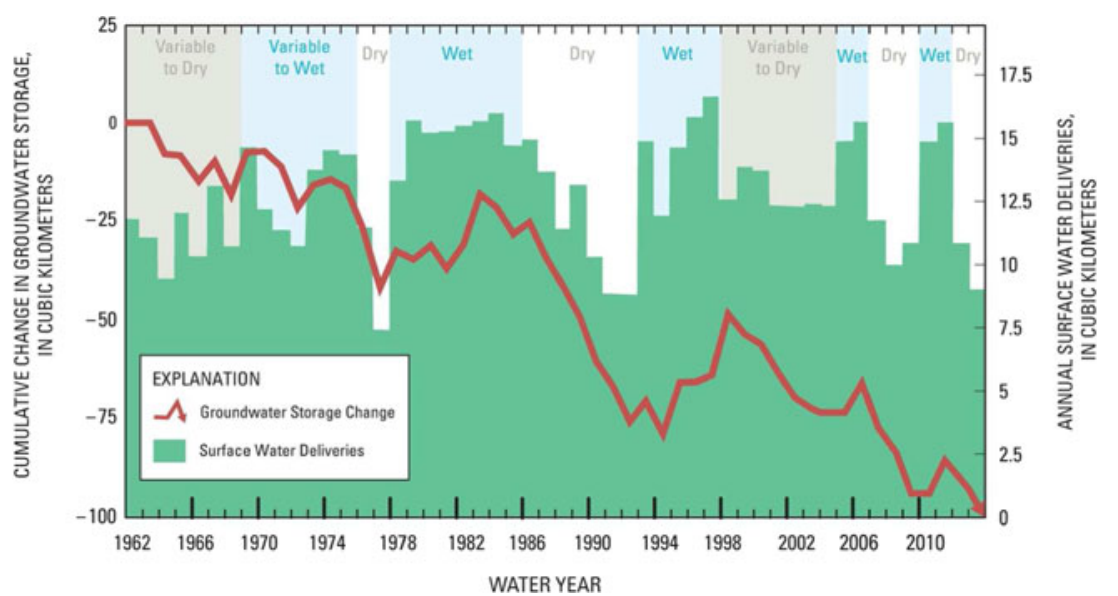

some parts of the valley, which was accompanied by a steady recovery of groundwater levels and a reduced rate of aquifersystem compaction and land subsidence in some areas (Ireland 1986). For brevity, throughout this paper, the term subsidence will be used to refer to aquifer-system compaction and the associated land subsidence.

The objective of this paper is to describe changes in water availability and competition for water in the Central Valley as well as to evaluate the influence of climate variability and human action on subsidence, particularly during the latest drought periods. In response to the competition for water, a number of water-related issues have gained prominence: surface-water availability, conjunctive use, managed aquifer recharge, land-use change, subsidence, and effects of climate variability. Independent of climatic variability, which is discussed later, surface-water deliveries have declined in recent years due to water-quality and biologic issues principally in the Sacramento-San Joaquin Delta - the 'heart' of the state's water delivery system (Ingebritsen and Ikehara 1999) - and agreements associated with surface-water allocations (Fig. 2). For example, the agricultural service contract allocation from the Central Valley Project south of the Delta was less than $50 \%$ of the 1952-1990 average for each of the years 2009-2011 and has been less than two thirds that allocation for each year since 2000 (B. Martin, San Luis Delta Mendota Water Authority, written communication, 2015).

Climate variability has had profound effects on the Central Valley hydrologic system. During droughts, surface water is less available and groundwater pumpage increases. During the droughts of 1976-1977 and 1987-1992, diminished availability of surface water led to reduced surface-water deliveries and increased groundwater pumpage, thereby reversing the overall trend of groundwater-level recovery and re-initiating subsidence in the San Joaquin Valley. Following each of these droughts, recovery to pre-drought water levels was rapid and subsidence virtually ceased (Swanson 1998; Galloway et al. 1999). During the more recent droughts of 2007-2009, and 2012-present, groundwater pumping and subsidence has increased in some parts of the valley.

To provide information to stakeholders addressing these issues, the US Geological Survey (USGS) Groundwater Resources Program supported a detailed assessment of groundwater availability of the Central Valley aquifer system that includes: (1) the present status of groundwater resources; (2) how these resources have changed over time; and (3) tools to assess system responses to stresses from future human uses and climate variability and change. The principal product of this assessment is a tool referred to as the Central Valley Hydrologic Model (CVHM) that accounts for integrated, variable water supply and demand, and simulates surface-water and groundwater flow, and subsidence across the entire Central Valley system (Faunt 2009; Figs. 1 and 2).

The CVHM simulates groundwater and surface-water flow, irrigated agriculture, subsidence, and other key processes in the Central Valley on a monthly basis. This model was developed at scales relevant to water management decisions for the entire Central Valley aquifer system. Subsidence, an important consequence of intense groundwater pumpage in susceptible aquifer systems, especially in the San Joaquin Valley, is specifically simulated. Recently, this model was extended through water year 2014 by including a scenario based on updated surface-water inflows and deliveries, updated land-use maps, and climate data (precipitation and reference evapotranspiration). In part, this extension was done to simulate the impact of land-use changes, managed aquifer recharge, and the more recent droughts on subsidence.

\section{Land-use changes, managed aquifer recharge, and drought}

The hydrology of the present-day Central Valley is driven by surface-water deliveries and associated groundwater pumpage, which in turn reflect the spatial and temporal 
variability in climate, water availability, and land use. Since 2000, land use in some parts of the Central Valley has trended toward the planting of permanent crops (vineyards and orchards) replacing non-permanent land uses such as rangeland, field crops, or row crops (Fig. 3). This may have the effect of 'demand hardening,' which refers to the need for stable water supplies to irrigate crops where the land cannot be easily fallowed; however, in some areas, more water efficient irrigation methods have been implemented, more water efficient crops planted, and/or land has been fallowed.

Based on the CVHM simulation, since the majority of the surface-water delivery system has been in place (early 1970s), on average about $43 \%$ of the water supply of the Central Valley has been met by groundwater (ranging from about $30 \%$ during wet years to $70 \%$ during extremely dry years). Central Valley farmers have drilled more wells and increased their groundwater pumping to compensate for reduced surface-water supplies and increased water demands of permanent crops. During the recent drought (2012-present), groundwater is used to meet about $70 \%$ of the demand. The proportion is expected to increase in the near future if surface water availability declines or remains at current levels, particularly given the increase in permanent crops.

The increased pumping has stressed the aquifer system, which has had an overall loss in groundwater storage for decades. Since 1962 groundwater storage in the Central Valley aquifer system has been depleted at an average rate of $1.85 \mathrm{~km}^{3} /$ year and at more than twice this rate during the latest drought (Fig. 2). This rate is likely to increase if dry conditions persist. Despite the worst drought in modern history, California agriculture realized record profits in 2013 and 2014, driven in part by US economic growth and expanding international markets (California Department of Water Resources 2014); however, under state laws enacted in 2014, the Central Valley groundwater basin must be sustainable by 2042. In order to meet these requirements, dramatic changes will need to be made.

The California Sustainable Groundwater Management Act (SGMA) requires that agencies responsible for high- and medium-priority groundwater basins in California develop a plan and reach sustainability. SGMA recognizes that groundwater is best managed at the local or regional level and that there are geographic, geologic, and hydrologic differences accounting for groundwater supply. The goal of this legislation is reliable groundwater management, which it defines as "the management and use of groundwater in a manner that can be maintained during the planning and implementation horizon without causing undesirable results" (California Department of Water Resources 2014). The act provides substantial time-20 years - for local agencies to implement plans and achieve long-term groundwater sustainability. Undesirable results are defined as any of the following effects:

- Chronic lowering of groundwater levels (not including overdraft during a drought if a basin is otherwise managed)

- Significant and unreasonable reduction of groundwater storage

- Significant and unreasonable seawater intrusion

- Significant and unreasonable degraded water quality, including the migration of contaminant plumes that impair water supplies

- Significant and unreasonable land subsidence that substantially interferes with surface land uses

- Depletions of interconnected surface water that have significant and unreasonable adverse effects on beneficial uses of the surface water.

Various agencies are implementing new projects to increase groundwater storage. Managed aquifer recharge (MAR) projects that have been used for a number of years are expanding in popularity and intensity. In the Central Valley, MAR is primarily done through surface-water impoundments in proximity to water supply and delivery systems in the southern part of the Central Valley in Fresno and Kern counties. Most of the impoundments are located on alluvial fans of the glaciated portions of the Sierra Nevada. These fans consist of sandy sediments that are highly
Fig. 3 Graph showing change in major land-use types in California's Central Valley based on US Department of Agriculture (2000-2013) California County Agricultural Commission reports. Field crop land-use area accounted for about $40,000 \mathrm{~km}^{2}$ for the period, and is not shown in the graph

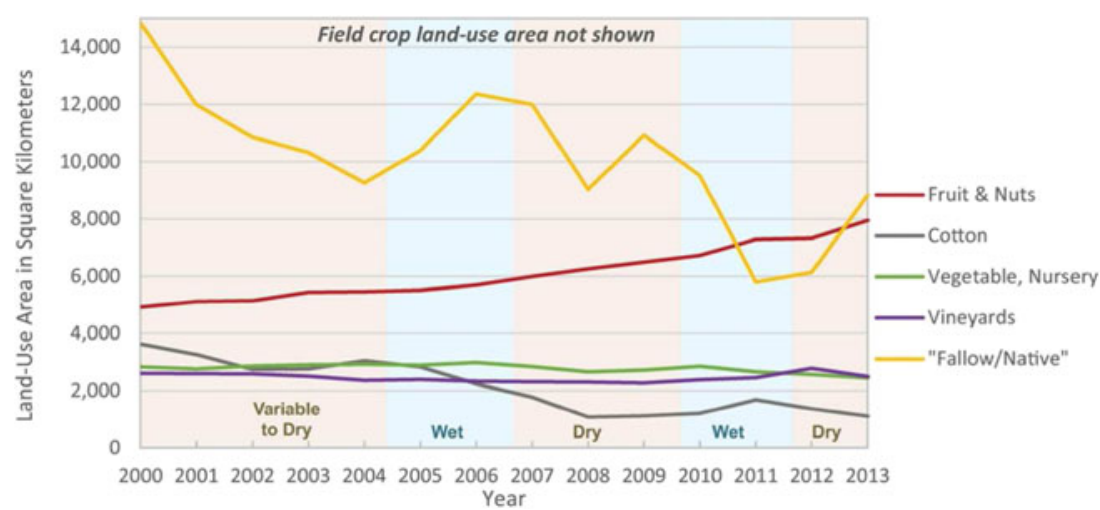


permeable and, therefore, are well suited for groundwater recharge through infiltration and later recovery of the recharged groundwater by pumping wells. The artificial recharge and recovery (withdrawal) for ten MAR projects between 1966 and 2014 are shown in Fig. 4. In general, artificial recharge and recovery correspond with climatic wet and dry periods: more water was artificially recharged and less was recovered during wet years and less water was artificially recharged and more was recovered during dry years. Although the recovery data is less complete than artificial recharge data, where the data were available, the highest volumes of recovery did occur during drought periods such as 2007-2009 and 2012-present (Fig. 4). Although these projects are augmenting groundwater storage with large amounts of water, other projects will be needed to either increase recharge or decrease water use in order to meet sustainability objectives.

\section{Land subsidence and groundwater levels}

Sneed and Brandt (USGS, "Land Subsidence in the San Joaquin Valley, California, USA 2007-2014", unpublished paper; Ninth International Symposium on Land Subsidence, Nagoya, Japan, 15-19 Nov 2015) used interferometric synthetic aperture radar (InSAR), continuous global positioning systems (CGPS), and extensometer data to determine the location, extent, and magnitude of subsidence in select areas of the San Joaquin Valley. Many of the details from their analyses are included in this section. Analysis of interferograms generated from synthetic aperture radar images from the European Space Agency's ENVISAT satellite and the Japan Aerospace Exploration Agency's ALOS satellite acquired between 2008 and 2010 indicated $50-540 \mathrm{~mm}$ of subsidence in two large agriculturally dominated areas in the San Joaquin Valley. One area is centered near the town of El Nido (2, $\left.100 \mathrm{~km}^{2}\right)$ and the other near the town of Pixley $\left(5,500 \mathrm{~km}^{2}\right.$; Fig. 5). The period 2008-2010 is shown in Fig. 5 because suitable InSAR data were not available for 2010-2014. As a result, CGPS data collected during 2007-2015 were used to generate subsidence time series. CGPS confirmed the InSARderived rates and generally indicated that these rates persisted or accelerated through 2015 (Fig. 6). The CVHM also simulated these persistent and in some areas accelerating rates through 2014.

To help explain the variability in location and magnitude of subsidence, computed subsidence was compared with local geology information and water-level measurements retrieved from USGS and California Department of Water Resources databases (Figs. 5 and 6a). Simulated subsidence from CVHM was used to further evaluate the spatial extent and magnitude of subsidence during the period 1962-2014 (Fig. 7).

The magnitude and rate of subsidence varies based on the hydraulic and mechanical properties of the saturated geologic materials constituting the aquifer system and on the consolidation history of the aquifer system. Therefore, the extent of subsidence was compared with the extent of fluvial fans from the Sierra Nevada (Weissmann et al. 2005; Figs. 1 and 5) and also to groundwater levels (Fig. 6a). In general, valley

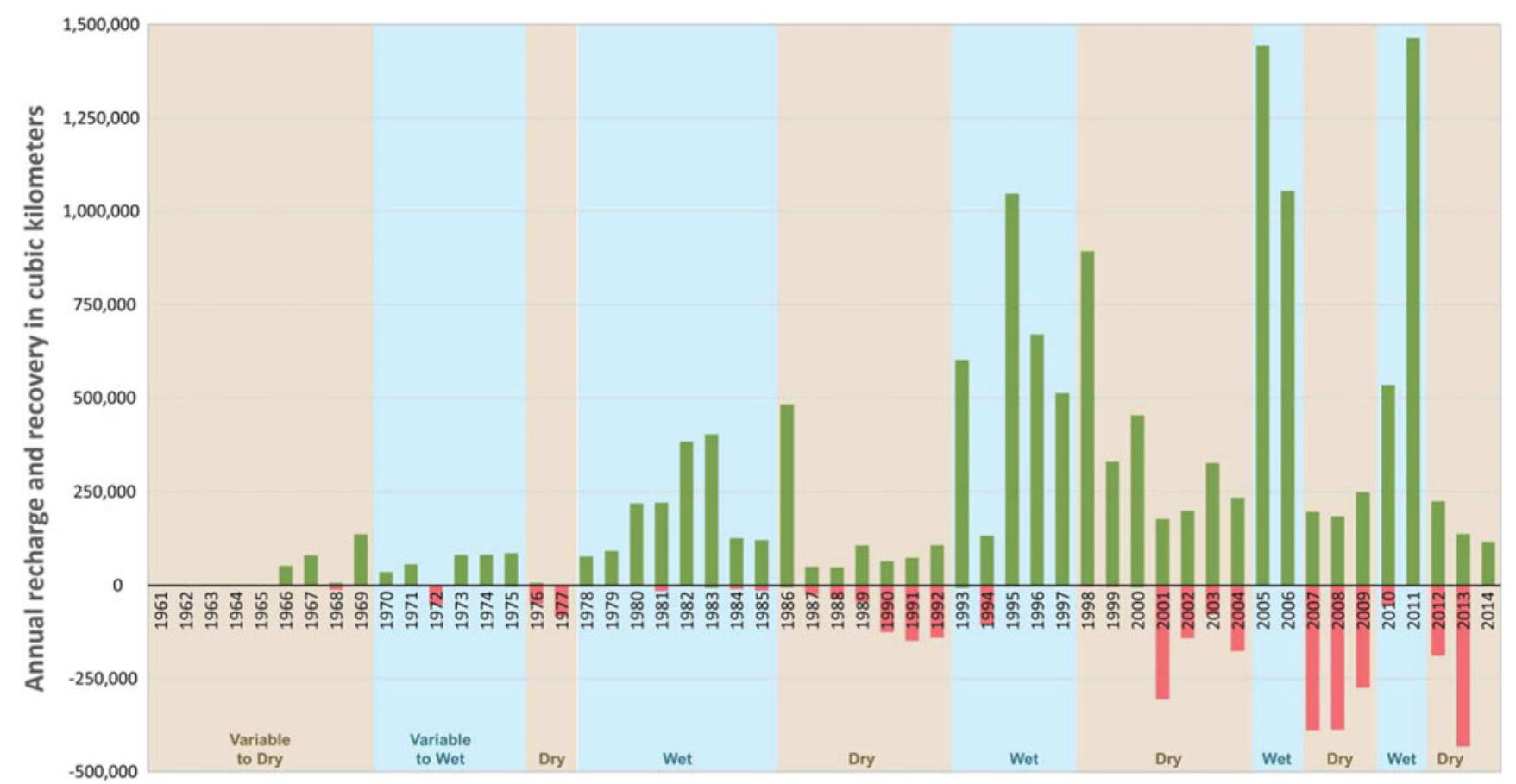

Fig. 4 Graph showing annual artificial recharge and recovery of the recharged water for managed aquifer recharge (infiltration of impounded surface water) and recovery projects between 1961 and 2014 in California's Central Valley 


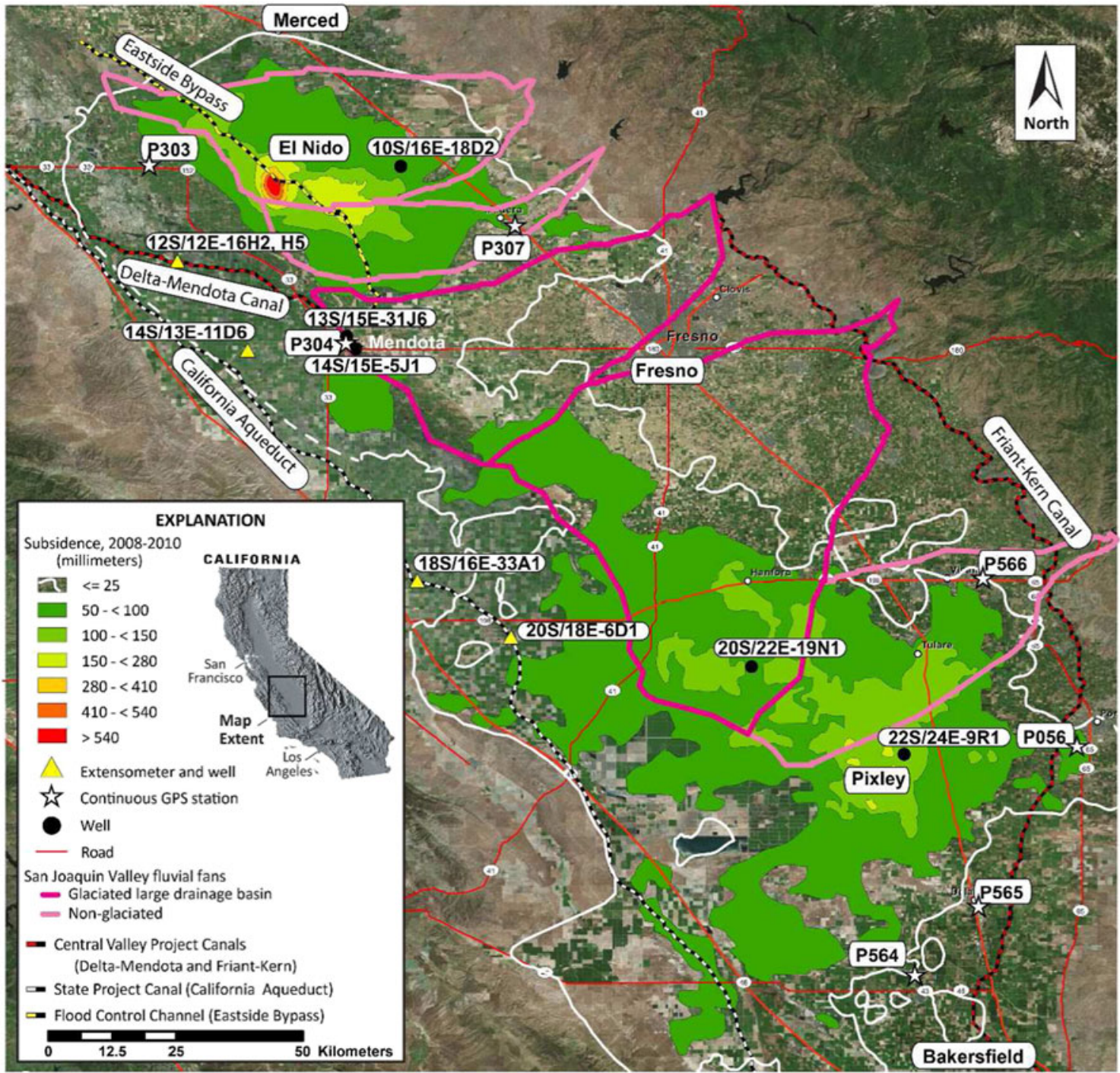

Fig. 5 Map showing estimated regions of subsidence derived from interferograms for 2008-2010, glaciated and non-glaciated fluvial fans, locations of extensometers, continuous GPS stations, and selected surface-water conveyance infrastructure

deposits sourced from the Coast Ranges and the non-glaciated fluvial fan deposits sourced from the Sierra Nevada are finer grained and more compressible than the coarser-grained sediments, resulting in greater subsidence under equivalent applied stresses (declining groundwater levels). Conversely, the upper reaches of the large drainage area glaciated fluvial fans that are relatively coarser grained and have much lower rates of subsidence (Fig. 5). Following the theory of aquifer-system compaction embodied in the aquitard drainage model (Galloway and Burbey 2011), the consolidation history of an aquifer system establishes the preconsolidation stress, which is often represented by the previous lowest groundwater level (highest effective or intergranular stress). The relation of current groundwater levels to the previous lowest water level controls whether subsidence is inelastic (permanent) or elastic (recoverable). Permanent subsidence occurs as a result of rearrangement of fine-grained materials when the preconsolidation stress is exceeded (current water levels lower than historical lows); whereas recoverable (elastic) subsidence occurs when the preconsolidation stress is not exceeded (current water levels higher than historical lows).

Since spring 2008, groundwater levels are at all-time historical lows (for period of record) in most areas of the southern San Joaquin Valley and portions of the Sacramento Valley. These areas exhibit groundwater levels more than $15 \mathrm{~m}$ below previous historical lows experienced sometime prior to 2000. There are many areas of the San Joaquin Valley where recent groundwater levels are more than $30 \mathrm{~m}$ below previous historical lows and correspond to areas of recent subsidence. According to the California Department of Water Resources (2014), groundwater levels in $55 \%$ of the long-term wells $(1,718$ of 3,124$)$ in the San Joaquin Valley and $36 \%$ of the long-term wells (216 of 599 ) in the Sacramento Valley are at or below the historical spring low levels. Groundwater levels declined during these 
Fig. 6 Graph showing vertical displacement (land subsidence) during 2004-2015 at a GPS station P304 and depth to water below land surface in a nearby well during 2004-2015; and b GPS station P303. See Fig. 5 for GPS and well locations
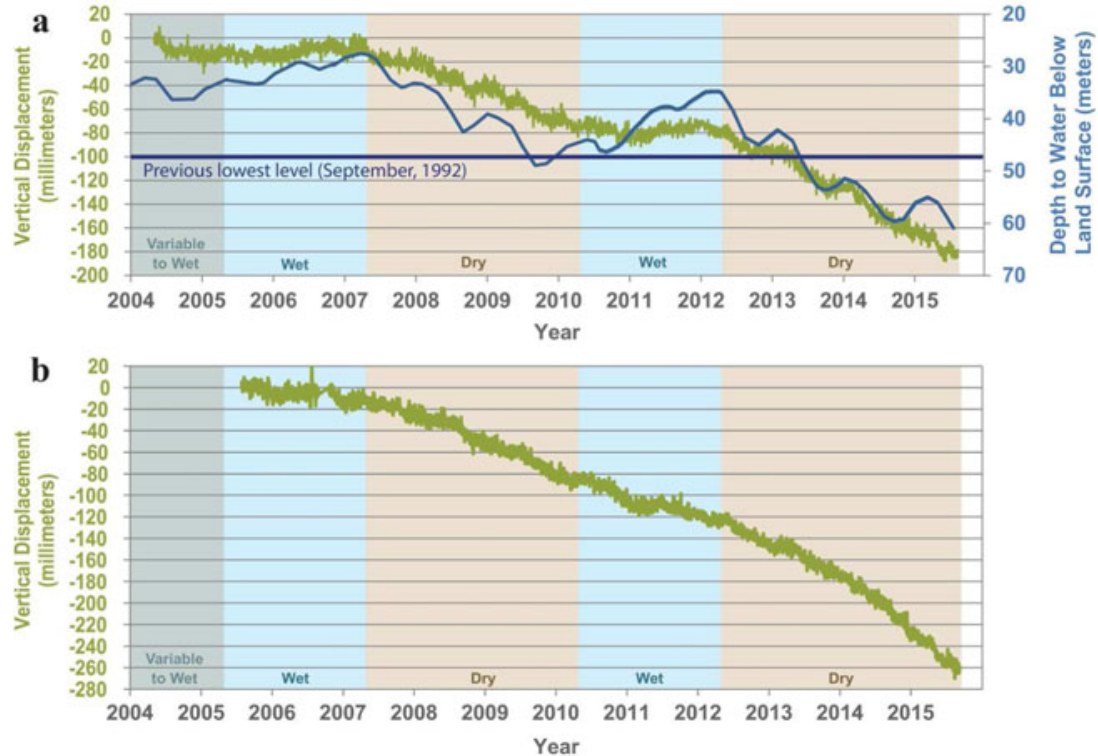

periods in response to increased pumping, approaching or surpassing historical low levels. As groundwater levels dropped, subsidence occurred in many areas.

The large recently subsiding areas in the San Joaquin Valley include areas that subsided historically; however, some of the areas of maximum subsidence have changed. The Tulare-Wasco area (Figs. 5 and 7) had substantial subsidence both historically and recently, the Los Banos-Kettleman City area (Figs. 5 and 7) has substantially less subsidence recently compared to historically - where maximum subsidence during 1926-1970 was about $4 \mathrm{~m}$ (Ireland 1986) - and the El Nido area has substantially more subsidence recently compared to historically (Ireland 1986; Sneed et al. 2013; Farr et al. 2015). More than $120 \mathrm{~mm}$ of subsidence occurred over a large part of the southern subsiding area during 2007-2010 (Fig. 5). In some places nearly $900 \mathrm{~mm}$ of subsidence occurred during this period. The maximum rate of recent subsidence $(250 \mathrm{~mm} /$ year $)$ is about twice the maximum rate that occurred historically in the area $(200 \mathrm{~mm} /$ year$)$.

The largest subsidence magnitude in the San Joaquin Valley during 2007-2014 was measured and simulated near El Nido (Figs. 5 and 7). The interferograms are the only measurements that captured the maximum magnitudes of subsidence because the CGPS stations and extensometers are located on the periphery of the most rapidly subsiding area (Fig. 5). The interferograms indicated a local maximum of about $540 \mathrm{~mm}$ during January 2008-January 2010, or $270 \mathrm{~mm} /$ year, which is among the highest rates ever measured in the San Joaquin Valley. The subsidence measured at nearby CGPS station P303 was about $50 \mathrm{~mm}$ during the same time period, indicating a large subsidence gradient between the two locations (Figs. 5 and 6b). The years 2010-2012 was a nondrought period but a continued high rate of subsidence occurred during this period near El Nido (Fig. 6b). Much of the area where subsidence is occurring near El Nido has little access to surface water for irrigation supplies regardless of climate conditions. This fact, coupled with changing land use explains the continued high rate of subsidence. Residual (delayed) compaction due to the slow equilibration of fluid pressures in relatively thick, interbedded, low-permeability fine-grained units in the aquifer system also may be a factor. Vertical displacement at P304 indicates that most subsidence occurred during drought periods and very little occurred between drought periods (Fig. 6a). This area received surface water, when it was available between drought periods. The cessation of subsidence between drought periods, when water levels recovered, indicates that residual compaction was not very important in this area. Assuming the same rate of subsidence occurred during 2007-2014 as occurred during 20082010 at the local subsidence maximum near El Nido, about $2 \mathrm{~m}$ of subsidence may have occurred during 2007-2014. The CVHM simulates slightly more than $2 \mathrm{~m}$ of subsidence in this area (Fig. 7).

In parts of the El Nido subsidence area, where the planting of permanent crops has increased, groundwater was either the primary source of water or groundwater pumping increased when surface-water availability was reduced, and groundwater levels declined to near or below historical lows during 2007-2010 and 2012-2014. The area with the highest rate of subsidence is correlated with rates of groundwater extraction where groundwater is used to irrigate (yearround) permanent crops (vineyards and orchards) that are replacing non-permanent land uses such as rangeland, field crops, or row crops (USDA 2000-2013; Fig. 3). The correlation between high rates of subsidence and water levels near or below historical lows indicates that the preconsolidation stress was exceeded and the subsidence is mostly permanent near El Nido. 
Fig. 7 Map showing simulated cumulative subsidence for water years 1962-2014 along with the identification of prominent historical (pre-2000) areas of subsidence

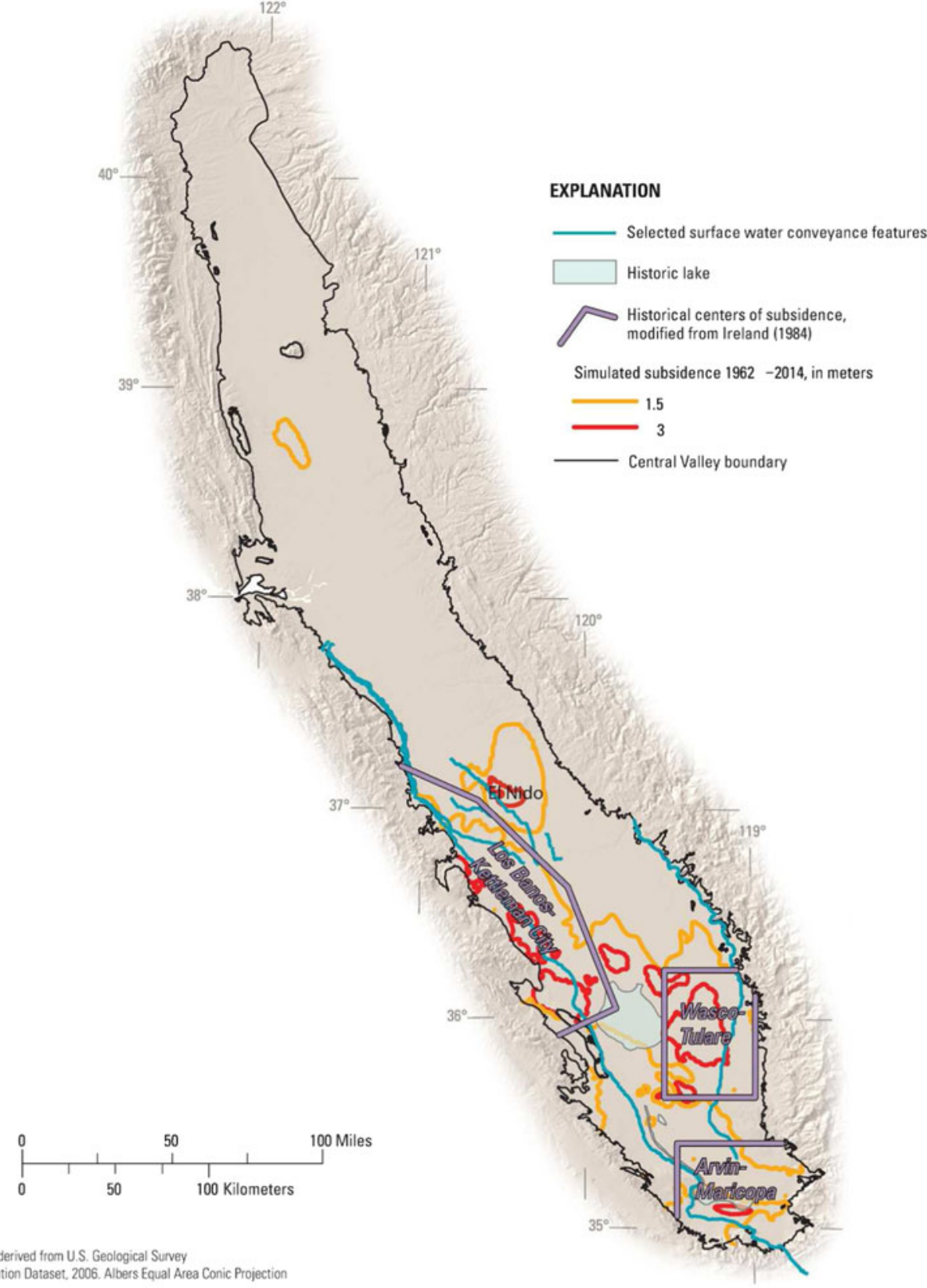

The Pixley subsidence area is really more extensive than the El Nido subsidence area, but subsided at a lower rate during 2007-2014. Similar to the El Nido area, the interferograms provided the only measurements that captured the maximum subsidence magnitudes because the CGPS stations and extensometers are located on the edges of the most rapidly subsiding area (Fig. 5). The interferograms indicated a maximum subsidence of about $180 \mathrm{~mm}$ during January 2008January 2010 (Fig. 5). If it is assumed that the rate of subsidence during 2007-2014 was equivalent to the rate during 2008-2010 at the local maximum near Pixley, about $0.7 \mathrm{~m}$ of subsidence may have occurred there during 2007-2014. Published subsidence rates during 2007-2010 ranged from about 0.2 to $0.25 \mathrm{~m} /$ year (Farr and Liu 2015; Farr et al. 2015), which are smaller than the $0.34 \mathrm{~m} /$ year rates, described as preliminary by LSCE et al. 2014). Farr et al. (2015) utilized InSAR to estimate subsidence rates in the Central Valley between May 2014 and January 2015, i.e., in the third year of California's ongoing severe drought. They measured as much as $0.35 \mathrm{~m}$ of subsidence near the local maximum subsidence area near Pixley for the 8-month period (equivalent to a rate of about $0.5 \mathrm{~m} /$ year).

Data from the four CGPS stations and two extensometers near the periphery of the Pixley subsidence area show seasonally variable subsidence rates, with different interannual characteristics. Vertical displacement at P564 and P565 indicated 
that most subsidence occurred during drought periods and very little occurred between drought periods. This suggests that this area received other sources of water, most likely surface water, when it was available between drought periods, and also that residual compaction was not very important in this area. Vertical displacement at P056 and P566 indicated subsidence at fairly consistent rates during and between drought periods. These fairly consistent subsidence rates are in areas with limited surface water availability and where groundwater is the primary water source. CGPS and extensometer data indicated an increased subsidence rate during 2014, the third year of drought. In the Pixley area, groundwater pumping continued or increased when surface-water availability was reduced, and groundwater levels declined to near or below historical lows during 2007-2010 and 2012-2014. Similar to the El Nido area, because the high rates of subsidence in the Pixley area are correlated with groundwater levels near or below historical lows, the subsidence is interpreted to be mostly permanent. Similar subsidence magnitudes for these periods are simulated by CVHM but the spatial patterns are somewhat different. These differences are attributed in part to the grouping of farms and agencies accepting surface-water deliveries and calculating demand for the water accounting in this part of the CVHM.

Groundwater pumping has resulted in subsidence which has caused damage to infrastructure in the San Joaquin Valley. Bridges, roads, buried irrigation pipelines, land leveling of fields, and wells have been altered and/or damaged by subsidence in the San Joaquin Valley (Sneed et al. 2013). In particular, serious operational, maintenance, and constructiondesign problems for the California Aqueduct, the DeltaMendota Canal, the Outside Canal, and other regional and local water-delivery and flood-control structures have been documented (Sneed et al. 2013; LSCE et al. 2014). Costs to address damage to surface-water conveyance infrastructure are estimated at more than $\$ 1.3$ billion (2013 dollars) during 1955-1972; cost estimates for subsidence-related damages incurred in subsequent years are unavailable (LSCE et al. 2014).

\section{Summary and conclusions}

Groundwater and surface water are generally used conjunctively in the Central Valley (Williamson et al. 1989; Faunt 2009). During recent drought periods (2007-2009 and 2012-present), groundwater pumping has increased. This increase is likely related to, among other things, the combination of declines in surface-water allocations, drought and land-use changes. In response, groundwater levels declined to levels approaching or surpassing historical low levels, which has caused subsidence that is mostly permanent. In the San Joaquin Valley, this subsidence has caused alterations or damages to bridges, roads, buried irrigation pipelines, land leveling of fields, and wells (Sneed et al. 2013; LSCE et al. 2014). Large areas with recent subsidence in the San Joaquin Valley-El Nido and Tulare-Wasco and Los Banos-Kettleman City areas (LSCE et al. 2014) - do not have CGPS or borehole extensometers in the areas of maximum subsidence (Fig. 5); therefore, the actual subsidence rate cannot be monitored continuously.

Planning for the effects of continued subsidence in the area will be important for water agencies. As land use, managed aquifer recharge, and surface-water availability continue to vary, long-term groundwater-level and subsidence monitoring and modelling are critical to understanding the dynamics of historical and continued groundwater use resulting in additional groundwater-level and groundwater-storage declines, and associated subsidence. In some circumstances, the subsidence may occur long after the groundwater pumping has declined. Modeling tools such as the CVHM, can be used in the evaluation of management strategies to mitigate adverse impacts due to subsidence while also optimizing water availability. This knowledge will be critical for successful implementation of California's recent legislation aimed toward sustainable groundwater use. Furthermore, the CVHM and other numerical models can be used to simulate a variety of scenarios to evaluate the various implementation plans and ensure the long-term resilience of the Central Valley's interconnected hydrologic system.

Acknowledgments This paper was encouraged by Devin Galloway (guest editor for the theme issue 'Land Subsidence Processes', Hydrogeology Journal) and supported by the USGS Groundwater Resources Program. Peer reviews by Kevin Dennehy (USGS), Lenny Konikow, and Jim Borchers and input from Devin Galloway greatly improved the manuscript. Errors of omission and commission are the sole responsibility of the authors.

Open Access This article is distributed under the terms of the Creative Commons Attribution 4.0 International License (http:// creativecommons.org/licenses/by/4.0/), which permits unrestricted use, distribution, and reproduction in any medium, provided you give appropriate credit to the original author(s) and the source, provide a link to the Creative Commons license, and indicate if changes were made.

\section{References}

Bertoldi GL, Johnston RH, Evenson KD (1991) Ground water in the Central Valley, California: a summary report. US Geol Surv Prof Pap 1401-A, 44 pp

California Department of Water Resources (2014) Summary of recent, historical, and estimated potential for future land subsidence in California. http://www.water.ca.gov/groundwater/docs/Summary of Recent Historical Potential Subsidence in CA Final with Appendix.p̄f. Accessed 14 September 2015

Farr TG, Liu Z (2015) Monitoring subsidence associated with groundwater dynamics in the Central Valley of California using interferometric radar. In: Lakshmi V (ed) Remote sensing of the terrestrial water 
cycle. Geophysical Monograph 206, American Geophysical Union, Washington, DC, pp 397-406

Farr TG, Jones C, Liu Z (2015) Progress report: subsidence in the Central Valley, California. http://water.ca.gov/groundwater/docs/NASA REPORT.pdf. Accessed 14 September 2015

Faunt CC (ed) (2009) Groundwater availability of the Central Valley Aquifer, California. US Geol Surv Prof Pap 1766, 225 pp

Galloway DL, Burbey TJ (2011) Review: land subsidence accompanying groundwater extraction. Hydrogeol J 19(8):1459-1486. doi:10. 1007/s10040-011-0775-5

Galloway DL, Riley FS (1999) San Joaquin Valley, California: largest human alteration of the Earth's surface. In: Galloway DL, Jones DR, Ingebritsen SE (eds) Land subsidence in the United States. US Geol Surv Circ 1182:23-34,. http://pubs.usgs.gov/circ/circ1182/. Accessed 14 September 2015

Galloway DL, Jones DR, Ingebritsen SE (1999) Land subsidence in the United States. US Geol Surv Circ 1182, 175 pp

Ingebritsen SE, Ikehara ME (1999) Sacramento-San Joaquin Delta: the sinking heart of the state. In: Galloway DL, Jones DR, Ingebritsen SE (eds) Land subsidence in the United States. US Geol Surv Circ 1182, pp 83-94. http://pubs.usgs.gov/circ/circ1182/. Accessed 14 September 2015

Ireland RL (1986) Land subsidence in the San Joaquin Valley, California, as of 1983. US Geol Surv Water Resour Invest Rep 85-4196, 50 pp

Poland, JF, Lofgren, BE, Ireland, RL, Pugh, AG (1975) Land subsidence in the San Joaquin Valley, California, as of 1972. US Geol Surv Prof Pap 437-H, 78 pp

Luhdorff and Scalmanini Consulting Engineers (LSCE), Borchers JW, Grabert VK, Carpenter M, Dalgish B, Cannon D (2014) Land subsidence from groundwater use in California, report prepared by LSCE with support by the California Water Foundation. http:// californiawaterfoundation.org/wp-content/uploads/PDF/ 1397858208-SUBSIDENCEFULLREPORT_FINAL.pdf. Accessed 14 September 2015

Sneed M, Brandt J, Solt M (2013) Land subsidence along the DeltaMendota Canal in the northern part of the San Joaquin Valley, California, 2003-10. US Geol Surv Sci Invest Rep 2013-5142, 87 pp, doi:.10.3133/sir20135142. Accessed 14 September 2015

Swanson AA (1998) Land subsidence in the San Joaquin Valley, updated to 1995. In: Borchers JW (ed) Land subsidence case studies and current research. Proceedings of the Dr. Joseph F. Poland Symposium on Land Subsidence, Sacramento, Calif., October 45, 1995, Association of Engineering Geologists, Special Publ. no. 8, pp 75-79

United States Department of Agriculture (USDA) (2000-2013) California County Agricultural Commission reports: National Agricultural Statistics Service. http://www.nass.usda.gov/ Statistics_by_State/California/Publications/AgComm/Summary/ index.asp. Accessed 14 September 2015

Weissmann GS, Bennett G, Lansdale AL (2005) Factors controlling sequence development on Quaternary fluvial fans, San Joaquin Basin, California, USA. In: Harvey A, Mather A, Stokes M (eds) Alluvial fans: geomorphology, sedimentology, dynamics. Geol Soc Lond Spec Publ 251:169-186

Williamson AK, Prudic DE, Swain LA (1989) Ground-water flow in the Central Valley, California. US Geol Surv Prof Pap 1401-D, $127 \mathrm{pp}$ 